\title{
LIP4 gene expression from Candida viswanathii strain
}

Ronan C. Teixeira

Matheus M. Daude

Nayra M. L. de Oliveira

Alex Fernando Almeida ( $\square$ alexfernando@uft.edu.br)

Federal University of Tocantins https://orcid.org/0000-0001-5391-4621

Horllys G. Barreto

\section{Research}

Keywords: gene expression, carbon sources, lipase, polymerase chain reaction

Posted Date: May 20th, 2020

DOI: https://doi.org/10.21203/rs.3.rs-27743/v1

License: (a) (i) This work is licensed under a Creative Commons Attribution 4.0 International License.

Read Full License 
3 Ronan C. Teixeira ${ }^{1}$, Matheus M. Daude ${ }^{2}$, Nayra M. L. de Oliveira ${ }^{1}$, Alex F. de Almeida ${ }^{1, *}$, Horllys G.

$4 \quad$ Barreto $^{2}$

5

$6 \quad{ }^{1}$ Laboratory of Biotechnology, Food Analysis and Products, Habite - Biotechnology Companies

7 Incubator - Federal University of Tocantins, Gurupi, Tocantins, Brazil

$8 \quad{ }^{2}$ Molecular Analysis Laboratory - Federal University of Tocantins, Palmas, Tocantins, Brazil

9

10

11

12

13

14

15

16

17

18 *Corresponding author

19 Alex Fernando de Almeida

20 Laboratório de Biotecnologia, Análise de Alimentos e Produtos - LABAP

21 Habite - Incubadora de Empresas de Biotecnologia da UFT

22 Universidade Federal do Tocantins, Gurupi, Tocantins, Brazil

23 Postal code: $77.402-970$

24 Phone: +55633311 1604

25 E-mail: alexfernando@mail.uft.edu.br

26

27 


\section{Abstract}

30 Background: Lipases are hydrolases that catalyze the cleavage of triglyceride esters bonds, releasing 31 glycerol and free fatty acids. Candida genus can produce distinct isoforms of lipase, among of them, 32 Candida viswanathii strain is a potential lipase producer using hydrophobic carbons sources in which 33 produced high level of enzyme under submerged cultivation using olive oil as carbon sources. This enzyme 34 has commercially attractive due to characteristics desired in the industries processes. The genes responsible 35 for encoding the lipases comprise a family called LIP gene. C. viswanathii not have its genome sequenced 36 and are not available in annotated form through the GenBank nucleotide sequence database for lipase 37 production. The aim of this work was understanding at molecular level the effect of carbon sources to lipase 38 production, to identify and to analyses the gene expression of CvLIP4 from C. viswanathii on different 39 culture media.

40 Results: In silico analysis was carried out with LIP4 gene from Candida species. Degenerate primers were 41 designed and evaluated for expression in different conditions. CvLIP4 expression was evaluated using 42 carbon sources glucose, tributyrin, triolein and olive oil. Triolein and olive oil were strong inducer for $43 \quad C v L I P 4$ gene expression, while tributyrin was a weak inducer and glucose was strong repressor.

44 Conclusions: These results will contribute to further studies about regulation of the lipase genes expression 45 from C. viswanathii and heterologous expression of this enzyme to improve the catalytic conditions in 46 industries processes. 


\section{Background}

Lipases (E.C. 3.1.1.3) belong to a class of hydrolases and water-soluble enzyme which catalyses the hydrolysis of insoluble triacylglycerols to generate free fatty acids, diacylglycerols, monoacylglycerols and glycerol. They catalyze a variety of reactions including hydrolysis, transesterification and interesterification of other esters as well as the synthesis of esters, and exhibit a range of regio, enantio and stereoselective transformation properties [1]. Lipases are the most popular biocatalysts that have remarkable applications in promoting various biochemical processes in the industry. They are found to be successful in catalyzing numerous processes relevant to the food, pharmaceutical, leather, cosmetic, detergent, medical diagnostics, dairy, beverage, fatty acid, and paper industries [2].

Candida genera can produce several lipases isoform with different catalytic properties. The genes responsible for encoding the lipases comprise a family called LIP gene, being composed of several members and with different characteristics, such as the LIPI to LIP8 genes of C. rugosa, as well as other sequences of these genes deposited in the GenBank $[3,4]$. This gene family comprise a different catalytic behavior in terms of substrate specificity, thermal and $\mathrm{pH}$ stabilities. The differences in substrate specificity may be related to specific amino acid variations in the different parts that compose the catalytic machinery. The commercial CRL is actually a mixture of three Lip isoenzymes (Lip1, Lip2, Lip3) present in different proportions (e.g., the CRL mixture of Sigma is composed of 73\% Lip1, 8\% Lip2 and 19\% Lip3) with Lip1 being the major component [5].

Candida viswanathii was firstly isolated from wastewater of a Brazilian oil refinery Replan/Petrobras, Paulínia, São Paulo, Brazil) and used for biodiesel and hydrocarbon bioremediation [6]. Almeida et al. [7] described the $C$. viswanathii strain as a potential lipase producer using hydrophobic carbons sources in which produced high level of enzyme under submerged cultivation using olive oil as carbon sources. Biochemical properties of crude lipase showed optimum $\mathrm{pH}$ and temperature activities at 4.0 and $40{ }^{\circ} \mathrm{C}$, high thermal stability and activity in organic solvent [8]. The purified lipase presented high solvent stability and hydrolytic activity on natural triacylglycerols and soy lecithin [9]. C. viswanathii was also able to produce high level of lipase using vegetable oils from Brazilian Amazonian with different fatty acids 
compositions [10]. The aim of this work was to evaluate at molecular level the effect of carbon sources on LIP4 isoform expression of $C$. viswanathii by polymerase chain reaction under submerged cultivation conditions.

\section{Methods}

\section{Maintenance lineage}

C. viswanathii strain is maintained in Laboratory of Biotechnology, Food Analysis and Products (LABAP), Habite - Biotechnology Incubator Companies, Federal University of Tocantins - UFT. $C$. viswanathii was routinely cultivated on potato dextrose agar (PDA) for 3 days at $28{ }^{\circ} \mathrm{C}$ and then stored at $4{ }^{\circ} \mathrm{C}$.

\section{Culture conditions}

Cultures were also performed in PDA slants at the same conditions for inoculum preparation. Submerged cultivations were carried out in Erlenmeyer flasks $(250 \mathrm{~mL})$ containing $60 \mathrm{~mL}$ of modified Vogel liquid medium [11] supplemented with $0.2 \%(\mathrm{w} / \mathrm{v})$ yeast extract and $1.0 \%(\mathrm{w} / \mathrm{v})$ carbon sources (glucose, tributyrin, triolein or olive oil), $\mathrm{pH}$ 6.0. Flasks containing the liquid cultures were autoclaved at $121^{\circ} \mathrm{C}$ for $20 \mathrm{~min}$ and inoculated with $3 \mathrm{~mL}$ of cells suspension $\left(10^{7}\right.$ cells $\left./ \mathrm{mL}\right)$. Cultivation was carried out at $28{ }^{\circ} \mathrm{C}, 180 \mathrm{rpm}$ for $25 \mathrm{~h}$. After cultivations, biomasses were centrifugated at $4,000 \mathrm{rpm}, 4{ }^{\circ} \mathrm{C}$ for $5 \mathrm{~min}$. One hundred of biomass was macerated using liquid nitrogen and stores at $-80{ }^{\circ} \mathrm{C}$.

\section{In silico analyzes}

C. viswanathii strain does not have its genome sequenced and are not available in annotated form through the GenBank nucleotide sequence database. A survey of known coding sequences of LIP4 gene from Candida species using GenBank database (www.ncbi.nlm.nih.gov/genbank/). Analysis of the sequence's alignment of Candida tropicalis (XM_002548709.1), Candida albicans (AF191317.1) and Candida orthopsilosis (XM_003871089.1) were performed with the ClustalW program [12], followed by 
standard parameters. For the construction of the phylogenetic tree, the MEGA 7.0 program [13] was

adopted using the Neighbor-joining comparison model [14], with distance model $p$ and pair-wise suppression. The statistical bootstrap method was used for validation of the phylogenetic tree with 10,000 replicates [15].

\section{Design of degenerate primers}

The nucleotide sequences of several species of the Candida genus were aligned in the same clade of the phylogenetic tree, using the Multiple Sequence Alignment by CLUSTALW program. With the result of the alignment an image was made using the GeneDoc program, where the regions of greater similarity were evaluated. The degenerate primers were designed in the most conserved regions for the LIP4 gene, where the lowest degree of degeneration was obtained using the Primer Express v2.0 program of Applied Biosystems. For the use of degenerate bases was followed the information of the own manufacturer (https://www.thermofisher.com/br).

\section{Conventional PCR conditions}

Deoxyribonucleic acid (DNA) extraction was carried out using Ilustra Nucleon PhytoPure for small samples kit (GE Helthcare), following manufacturer's protocol. Samples purity were analyzed in spectrophotometer Nanodrop One (Thermo Fischer Scientific) and stored at $-20{ }^{\circ} \mathrm{C}$. Conventional PCR were carried out using kit GoTaq® Hot Start Green Master Mix, 2X (Promega), according manufacturers protocol. PCR reactions (T100 Thermal Cycler - Bio-Rad) were performed in reaction mixture in a total volume of $25 \mu \mathrm{L}$ in an Eppendorf as follow: $12.5 \mu \mathrm{L}$ GoTaq Hot Start Green Master Mix, $2 \mathrm{X}, 1.0 \mu \mathrm{L}$ of primer forward $[10 \mu \mathrm{M}], 1.0 \mu \mathrm{L}$ of primer reverse $[10 \mu \mathrm{M}], 1.5 \mu \mathrm{L}$ of DNA [100.0 ng/ $\mu \mathrm{L}]$ and $9.0 \mu \mathrm{L}$ of nuclease free water. PCR cycles conditions were carried out as follow: $95{ }^{\circ} \mathrm{C}$ for $5 \mathrm{~min}$ and 40 cycles with denaturation at $95{ }^{\circ} \mathrm{C}$ for $30 \mathrm{~s}$, annealing at $51.4^{\circ} \mathrm{C}$ for $45 \mathrm{~s}$, and final extension at $72{ }^{\circ} \mathrm{C}$ for $1 \mathrm{~min}$.

\section{Design of primers $C v L I P 4$}


The primers design LIP4 gene from $C$. viswanathii (named $C v L I P 4$ ) was carried out by analysis of sequencing results obtained previously compared to the sequences used to design the degenerate primers

\section{7}

(Table 1). From the sequence of $C v L I P 4$ to $C$. viswanathii obtained in the sequencing, the primers were designed using the Primer Express v2.0 program of Applied Biosystems.

\section{Table 1}

\section{Sequencing}

Amplified products were eluted with Illustra ${ }^{\mathrm{TM}} \mathrm{GFX}^{\mathrm{TM}}$ PCR DNA and Gel Band Purification (GE Healthcare) according manufacturer's protocol. Purified samples $2.0 \mu \mathrm{L}$ (50 ng/ $\mu \mathrm{L}$ ) were transferred to Eppendorf containing $1.0 \mu \mathrm{L}$ of primer forward $[10 \mu \mathrm{M}]$, and $4.5 \mu \mathrm{L}$ of nuclease free water. These samples were submitted to Myleus Biotechnology (Belo Horizonte, Brazil) for sequencing by capillary electrophoresis, using POP7 polymer and BigDye v3.1.

\section{RNA extraction, DNase treatment and cDNA synthesis}

For ribonucleic acid (RNA) total extraction, Trizol ${ }^{\mathrm{TM}}$ was used according manufacturer's protocol. Turbo DNA-Free ${ }^{\mathrm{TM}}$ (Applied Biosystems) was also used to eliminate possible trace amounts of contaminating genomic DNA according do kit instructions. The absence of DNA was also verified through PCR, using as template the total RNA. Nucleic acid quantification was assessed spectrophotometrically by measuring the absorbance at $260 \mathrm{~nm}$ using a NanoDrop One spectrophotometer (Thermo Fisher Scientific). RNA purity of samples was evaluated through the A260nm/A280nm and A260nm/A230nm ratio. This samples were stored at $-80^{\circ} \mathrm{C}$. Samples of treated RNA $(1,000 \mathrm{ng} / \mu \mathrm{L})$ with high-degree purity and integrity were used to cDNA synthesis using High-Capacity cDNA Revere Transcription (Applied Biosystems).

\section{Amplification of CvLIP4 by conventional PCR}

CvLIP4 amplification was performed using GoTaq ${ }^{\circledR}$ Hot Start Green Master Mix 2X (Promega) by conventional PCR according manufacturer's protocol. For each reaction with $12.5 \mu \mathrm{L}$ final volume were 
added 6.25 $\mu \mathrm{L}$ GoTaq Hot Start reen Master Mix 2X, $0.5 \mu \mathrm{L}$ primer forward $(10 \mu \mathrm{M}), 0.5 \mu \mathrm{L}$ primer reverse $(10 \mu \mathrm{M}), 0.75 \mu \mathrm{L}$ cDNA $(100 \mathrm{ng} / \mu \mathrm{L})$ and $4.5 \mu \mathrm{L}$ nuclease free water. PCR was run (T100 Thermal Cycler, Bio-Rad) with an initial step at $95^{\circ} \mathrm{C}$ for $5 \mathrm{~min}$ and 40 cycles with denaturation at $95^{\circ} \mathrm{C}$ for $45 \mathrm{~s}$, annealing at $59{ }^{\circ} \mathrm{C}$ for $45 \mathrm{~s}$, extension at $72{ }^{\circ} \mathrm{C}$ for $30 \mathrm{~s}$, and final extension at $72{ }^{\circ} \mathrm{C}$ for $5 \mathrm{~min}$. Samples were stored at $-20{ }^{\circ} \mathrm{C}$.

\section{Results}

C. viswanathii not have its genome sequenced and are not available in annotated form through the GenBank nucleotide sequence database for lipase production. For this study, in silico analysis was carried out with LIP4 gene from Candida species (Figure 1A). Namely CvLIP4 gene product was used to align the degenerate prime designed for C. viswanathii strain with LIP4 gene from C. orthopsilosis, C. albicans and C. tropicalis (Figure 1B), where the similarity between the sequences in black indicates similarity between the bases of all species, gray indicates that similarity occurs in at least two species and white means that there is no similarity.

Figure 1.

Candida species showed little differences in conserved regions from LIP4 gene. CvLIP4 gene was amplified from C. viswanathii using degenerated primers (Figure 2). In this experiment, it was observed one band of 1,000 bp (amplicon expected) and one unspecific product; however, the annealing temperature of $51.4{ }^{\circ} \mathrm{C}$ was more specific than $48.3{ }^{\circ} \mathrm{C}$ to produce the interest product.

Figure 2.

The amplification and expression of $C v L I P 4$ gene was evaluated by cultivation of $C$. viswanathii under minimal salt medium containing sole carbon sources e.g. glucose $(\mathrm{G})$, tributyrin (TB), triolein (TO) and 
olive oil (O) (Figure 3). In these conditions, CvLIP4 gene expression is directly associated to the carbon

source once the glucose was a strong repressor source, tributyrin a weak inducer source and triolein and olive oil were a strong inducer to $C$. viswanathii lipase production. Triolein and olive oil presented amplification bands with higher intensity when compared to tributyrin and glucose. Triolein and olive oil present oleic acid $\left(\mathrm{C} 18: 1 \Delta^{9}\right)$ in your fatty acid composition.

Figure 3.

\section{Discussion}

Candida species can express eight LIP gene family with a high amino acid identity and similarity among them [5]. In these work, CvLIP4 from $C$. viswanathii was identify among homologous sequence from Candida species and degenerated primers were designed and analyzed in different carbon sources. The highly similarity in sequence but partially different in regions among the yeast species studied in this work can offer distinct biochemical properties such as substrates molecules interactions, sugar content, hydrophobicity and isoelectric point. Brocca et al. [16] extends the family of known Lip genes from Candida rugosa to seven highly homologous sequences. However, five-lipase genes comprising lipase gene family of C. rugosa with $80-88 \%$ pair wise identity, in nucleotide sequence. All genes encoding these isozymes were located on the same chromosome, which suggests their origin through gene duplication.

The effect of culture conditions on the microbial growth e.g., carbon and nitrogen sources, not only influence the lipase production but also changed the pattern formation of multiple forms of lipase. $C$. viswanathii has strong repression of lipase expression compared to olive oil and triolein. The yeast follows a complex pattern of lipase production depending on the presence of multiple lipase encoding genes whose expression is modulate by carbon sources that can act as repressor (e.g. glucose), inducer sources (e.g. oleic acid) or neutral substrates which is employed in two-step fermentation, where the first step of biomass growth is followed by the induction of lipase gene expression [17]. In the first report about lipase production by $C$. viswanathii, Almeida et al. [7] related that this yeast can growth in several pure carbon sources such 
as glucose, galactose, mannitol sorbitol and glycerol but was not observed lipase production; on the other

217 hand, pure fatty acids and triacylglycerols were able to promote the microbial growth and lipase secretion.

218 On the other hand, the complex triacylglycerols were also evaluated according to presence of high

219 percentage of long chain fatty acids which observed that presence of oleic acid in the total composition of

220 fatty acids was the most important inducer to lipase production.

Oleic acid in widely described as main inducer source to true lipase production for many microorganisms. Olive oil contains approximately $80 \%$ oleic acid and it is considered a good inducer for

223 lipase synthesis by many microorganisms what could be related with the fact of the lipases hydrolyze

224 preferentially fatty acids residues at positions 1 and 3 of the glycerides, and some extracellular lipase requires oleic acid as stabilizer/activator [18]; and also to the presence of several tocopherols and other liposoluble vitamins that are important for microbial growth.

The weak intensity band formation using tributyrin source observed to $C \nu L I P 4$ gene expression by $C$. viswanathii can be explained due the specificity of true lipase to long-chain fatty acids ester. Lipases are activated on interfaces of insoluble lipid substrates oil-water, where the catalytic reaction is combined with various interfacial phenomena/processes. The catalytic mechanisms involved for lipase activity depend strongly on the mode of organization of the lipid substrates present in interfacial structures such as membrane bilayers, monolayers, micelles, vesicles, and oil-in-water emulsions [19]. A recombinant LIP4 isoform from C. rugosa (formerly Candida cylindracea) was previously related to have higher esterase activity toward long acyl-chain ester and lower lipase activity toward triglycerides [20]. Tributyrin present short-chain fatty acid ester in triacylglycerol which are soluble in water and does not provide an interface oil-water formation. True lipases display a hydrophobic lid structure on active-site that regulate the activity mechanism in the presence of interface oil-water, which rearranges its position leaving an open gate to the active center. Then, the position of the lid marks the difference between the open (active) or closed (inactive) forms of these proteins [21, 22]. On the other hand, Fikers et al. [23] and Lotti et al. [24] reported the repression of lipase production caused by glucose from culture both. 
244 This is the first report on gene expression from lipase family using $C$. viswanathii strain under 245 cultivation growth conditions. These results will contribute to further studies about regulation of the lipase 246 genes and heterologous expression of this enzyme and to understand and improve the catalytic conditions 247 in industries processes.

249 Acknowledgements

250 This work was financial supported by National Council of Technological and Scientific Development 251 (CNPq) (Process number 455754/2014-4). A.F. Almeida thank the Produtividade em Pesquisa da UFT 252 grant (Edital 10/2018). Coordenação de Aperfeiçoamento de Pessoal de Nível Superior - Brasil (CAPES)

253 - Finance Code 001. R.C. Teixeira thank the National Council of Technological and Scientific 254 Development (CNPq) to Scientific Initiate grant (PIBIC-CNPq).

Author's contributions

AFA and HGB conceived the study and supervised the experimental work; RCT and NMLO performed 259 the lipase production experiments and determined enzymatic activity; RCT, MMD and HGB performed 260 the in silico analysis, primer design and molecular analysis; RCT, AFA and HGB wrote the main 261 manuscript text, discussions and review. All the authors reviewed and approved the final manuscript.

\section{Funding}

264 National Council of Technological and Scientific Development (CNPq) (Process number 455754/2014-4)

266 Availability of data and materials

267 Please contact author for data requests. 
The authors declare that there are no conflicts of interest.

\section{$272 \quad$ References}

273 [1] Sharma R, Chisti Y, Banerjee U. Production, purification, characterization, and applications of 274 lipases. Biotechnol Adv 2001;19:627-62.

275 [2] Sarmah N, Revathi D, Sheelu G, et al. Recent advances on sources and industrial applications of 276 lipases. Biotechnol Prog 2018; 34:5-28.

277 [3] Longhi S, Fusetti F, Grandori R, et al. Cloning and nucleotide sequences of two lipase genes from 278 Candida cylindracea. BBA Gene Struct Expres 1999;21131:227-32.

279 [4] Lotti M, Grandori R, Fusetti F, et al. Cloning and analysis of Candida cylindracea lipase sequences. $280 \quad$ Gene 1993;124:45-55.

281 [5] Vanleeuw E, Winderickx S, Thevissen K, et al. Substrate-specificity of Candida rugosa lipase and its 282 industrial application. ACS Sust Chem Eng 2019;7;15828-44.

283 [6] Soares J, Mariano A, de Angelis D. Biodegradation of biodiesel/diesel blends by Candida viswanathii. 284 Afr J Biotechnol 2009;8:2774-78.

285 [7] Almeida A F, Taulk-Tornisielo S M, Carmona E C. Influence of carbon and nitrogen sources on lipase 286 production by a newly isolated Candida viswanathii strain. Ann Microbiol 2013;63:1225-34.

287 [8] Almeida A F, Tauk-Tornisielo S M, Carmona E C. Acid lipase from Candida viswanathii: production, 288 biochemical properties, and potential application. Biomed Res Int 2013:435818

289 [9] Almeida A F, Terrasan C R F, Terrone C C, et al. Biochemical properties of free and immobilized 290 Candida viswanathii lipase on octyl-agarose support: Hydrolysis of triacylglycerol and soy lecithin. 291 Process Biochem 2018;65:71-80.

292 [10] Gomes N B, Dias K B, Netto Teixeira M F, et al. Medium composition and Amazonian oils for 293 lipase production by Candida viswanathii. Acta Sci Technol 2018;40:35088

294 [11] Vogel H J. A convenient growth medium for Neurospora crassa (medium N). Microbiol Gen Bul $295 \quad 1956 ; 13: 42-43$. 
[12] Thompson J, Higgins D, Gibson T. Clustal-W - improving the sensitivity of progressive multiple

sequence alignment through sequence weighting, position-specific gap penalties and weight matrix choice. Nucleic Acids Res 1994;22:4673-80.

[13] Kumar S, Stecher G, Tamura K. MEGA7: Molecular evolutionary genetics analysis version 7.0 for bigger datasets. Mol Biol Evol 2016;33:1870-74.

[14] Saitou N, Nei M. The neighbor-joining method - a new method for reconstructing phylogenetic trees. Mol Biol Evol 1987;4:406-425.

[15] Sitnikova T, Rzhetsky A, Nei M. Interior-branched and bootstrap tests of phylogenetic trees. Mol Biol Evol 1995;12:319-33.

[16] Brocca S, Grandori R, Breviario D, Lotti M. Localization of lipase genes on Candida rugosa chromosomes. Curr Genet 1995;28:454-57.

[17] Lotti M, Brocca S, Porro D. High lipase production by Candida rugosa is associated with G1 cells. A flow cytometry study. Biotechnol Lett 2001;23:1803-08.

[18] Mafakher L, Mirbagheri M, Darvishi F, et al. Isolation of lipase and citric acid producing yeasts from agro-industrial wastewater. N Biotechnol 2010;27:337-40.

[19] Aloulou A, Rodriguez J A, Fernandez S, et al. Exploring the specific features of interfacial enzymology based on lipase studies. BBA-Mol Cell Biol L 2006;1761:995-1013.

[20] Tang S, Sun K, Sun G, et al. Recombinant expression of the Candida rugosa LIP4 lipase in Escherichia coli. Protein Exp Purif 2000;20:308-13.

[21] Fojan P, Jonson P H, Petersen M T, Petersen S B. What distinguishes an esterase from a lipase: a novel structural approach. Biochimie 2000;82:1033-41.

[22] Barriuso J, Vaquero M E, Prieto A, et al. Structural traits and catalytic versatility of the lipases from the Candida rugosa-like family: A review. Biotechnol Adv 2016;34:874-885.

[23] Fickers P, Nicaud J, Gaillardin C, et al. Carbon and nitrogen sources modulate lipase production in the yeast Yarrowia lipolytica. J Appl Microbiol 2004;96:742-49.

[24] Lotti M, Monticelli S, Montesinos J L, S. Brocca, et al. Physiological control on the expression and secretion of Candida rugosa lipase. Chem Phys Lipids 1998;93:143-148. 
325 Figure 1. Phylogenetic tree of Candida species that Lip4 gene encoded (A). Alignment of LIP4 gene 326 sequences in Candida species. Legend: CvLIP4: C. viswanathii; CoLIP4: C. orthopsilosis; CaLIP4: C.

327 albicans; CtLIP4: C. tropicalis. Blue line indicate the regions used to design specific primer for CvLIP4.

329 Figure 2. Conventional PCR amplification LIP4 using degenerate primers. Legend: M: molecular marker 330 weight

332 Figure 3. CvLIP4 gene amplification in different culture media. Legend: TR: tributyrin; TO: triolein; O:

333 olive oil; G: glucose. 
350 Table 1. Degenerate and design primer for LIP4 gene expression in C. viswanathii.

\begin{tabular}{|c|c|c|c|c|}
\hline Gene & & Primers $\left(5^{\prime}-3^{\prime}\right)$ & $\begin{array}{l}\text { MT } \\
\left({ }^{\circ} \mathrm{C}\right)\end{array}$ & $\begin{array}{l}\text { Amplicon } \\
\text { (bp) }\end{array}$ \\
\hline LIP4 & Degenerate primer & $\begin{array}{l}\text { F: AARRTTCARAACTCYTGGCA } \\
\text { R: ATKATCCAAGTYAAWGCARC }\end{array}$ & 51.4 & 1001 \\
\hline CvLIP4 & Design primer & $\begin{array}{l}\text { F:GCGGAGTTACCCTTTATTGGTGT } \\
\text { R:CCACGGACTGAGTTTAAGACAGC }\end{array}$ & 59.0 & 131 \\
\hline
\end{tabular}


A XMO02548709.1 Condica tropicalis MYA..

AF191317.1 Candida albicans secretory...

XMOO3871089.1 Candida athopsilosis ..

B
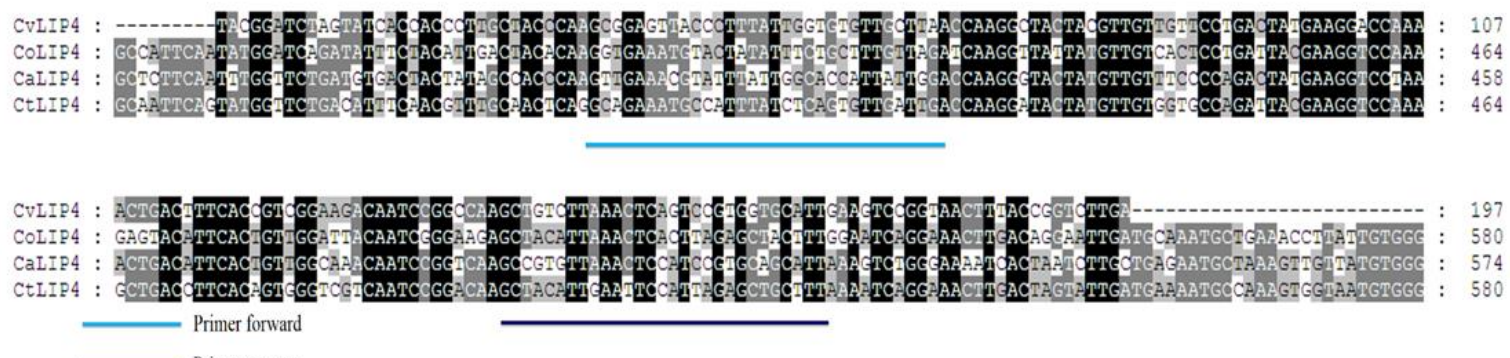

376 Figure 1. 


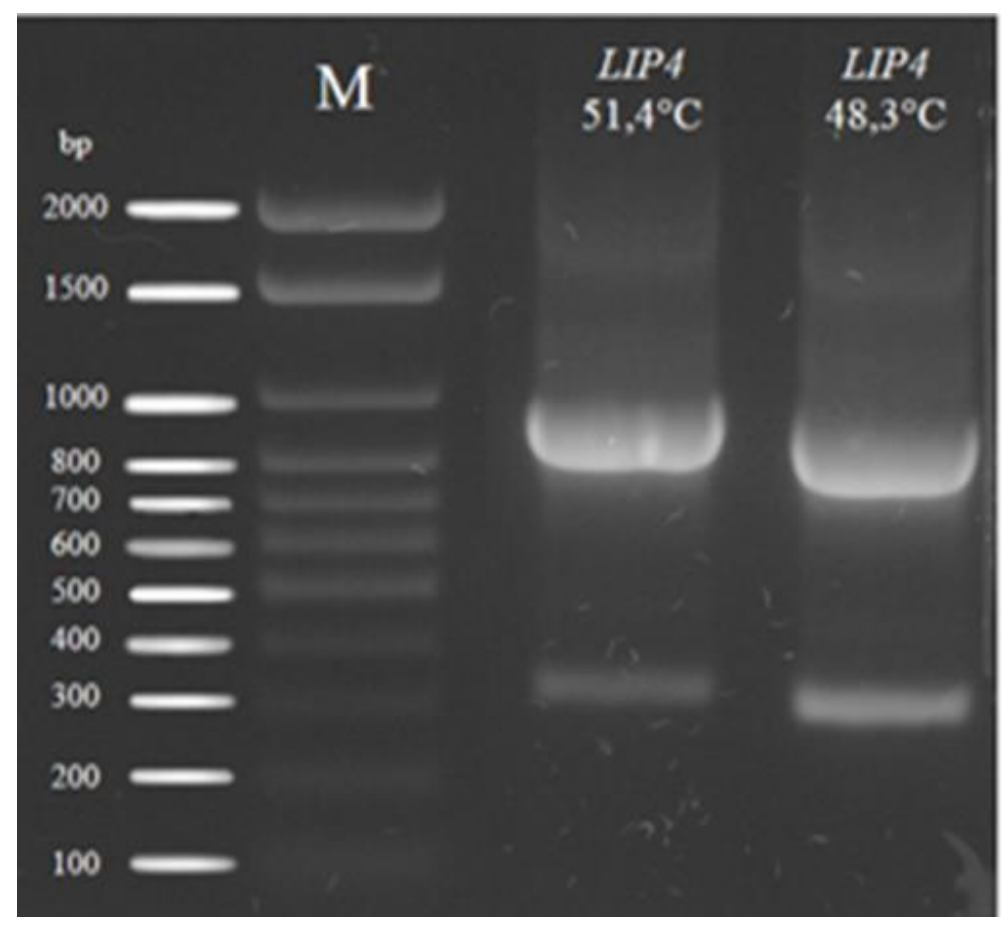

401

402 Figure 2.

403

404

405

406

407

408

409

410

411

412

413

414

415

416

417

418

419 


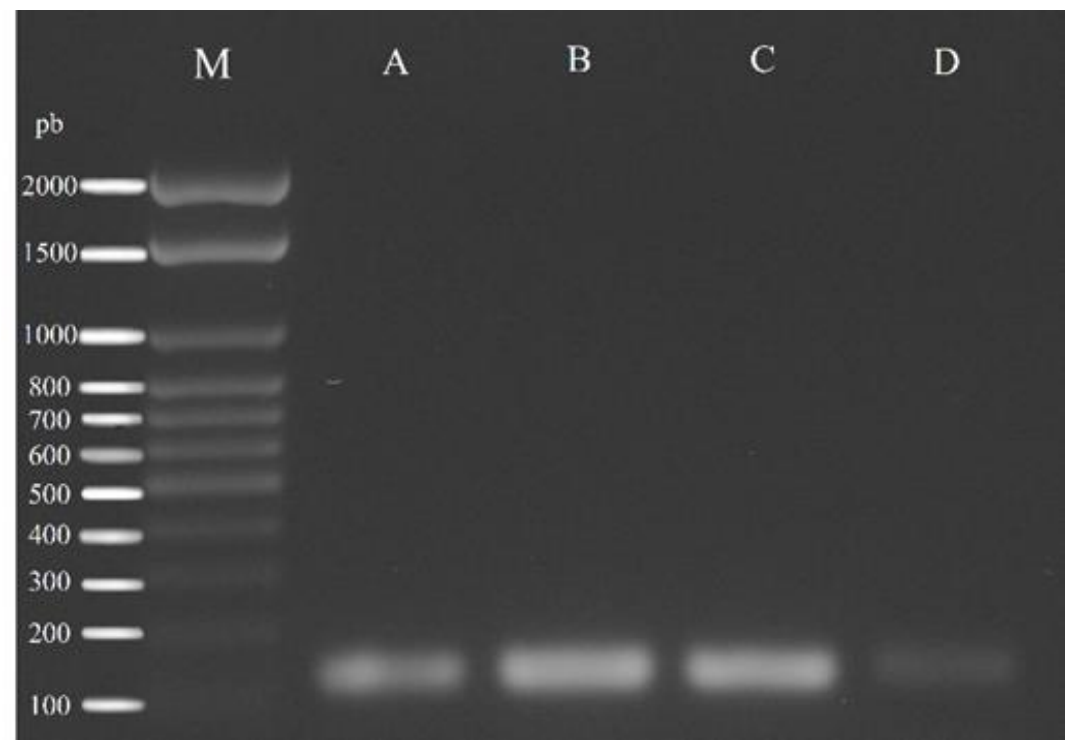

421 Figure 3. 


\section{Figures}

A XMOC2548709.1 Candica tropicalis MYA. . AF191317.1 Candida albicans secretory...

XM 003871089.1 Candicta orthopsilosis ...

B

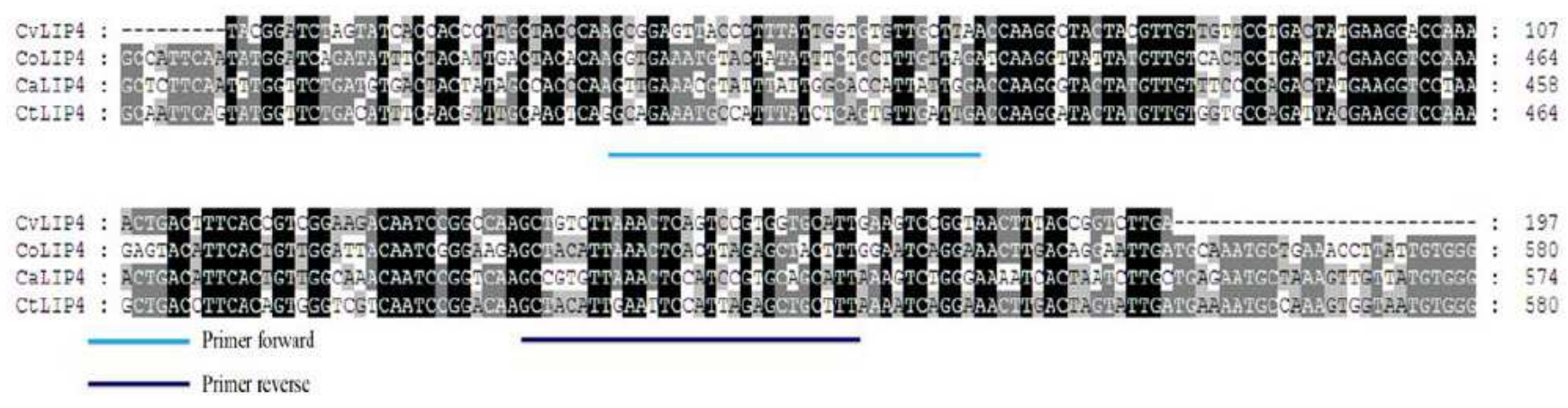

Figure 1

Phylogenetic tree of Candida species that Lip4 gene encoded (A). Alignment of LIP4 gene sequences in Candida species. Legend: CvLIP4: C. viswanathii; CoLIP4: C. orthopsilosis; CaLIP4: C. albicans; CtLIP4: C. tropicalis. Blue line indicate the regions used to design specific primer for CvLIP4. 


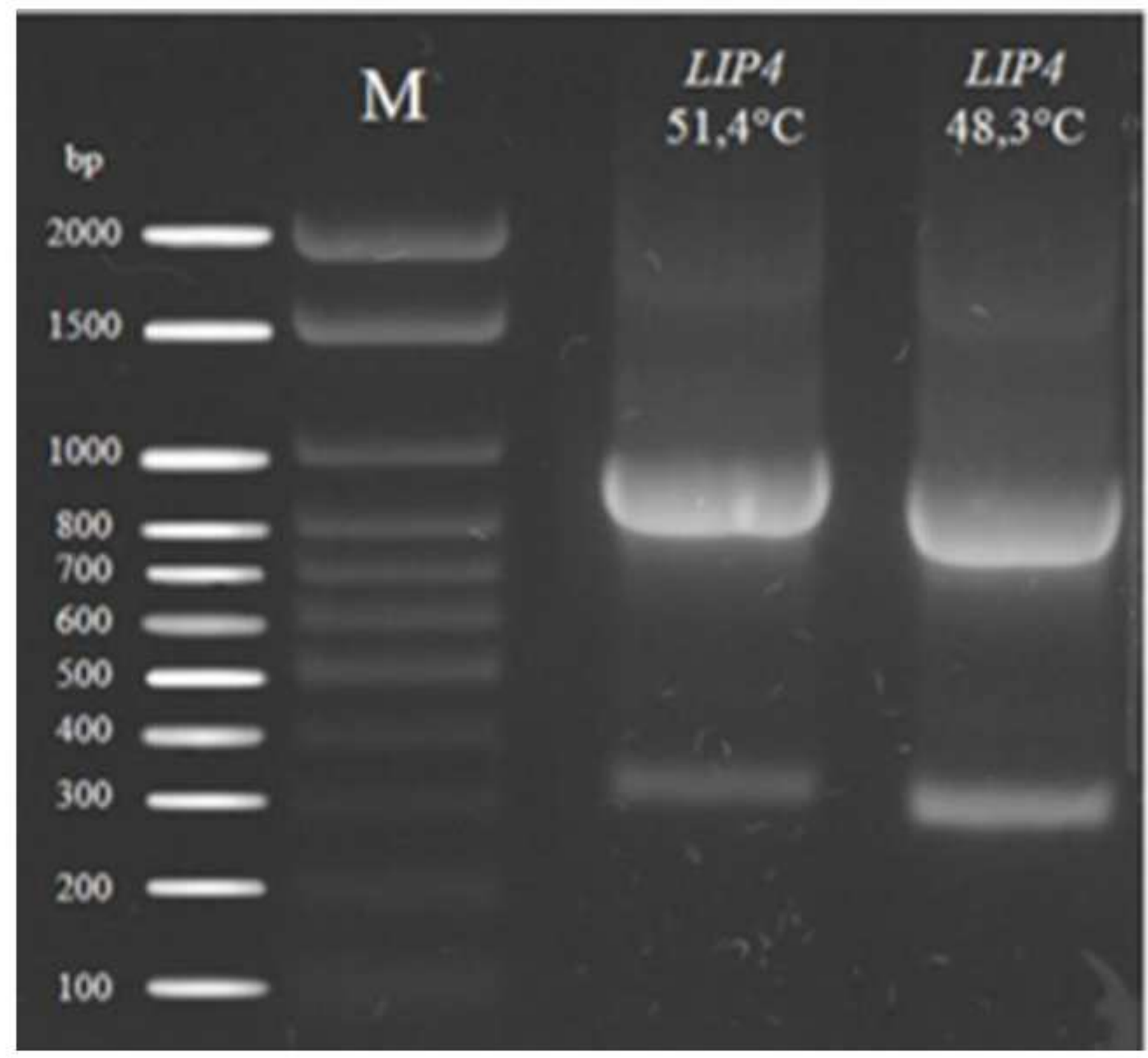

Figure 2

Conventional PCR amplification LIP4 using degenerate primers. Legend: M: molecular marker weight 


\section{M}

A

B

C

D

$\mathrm{pb}$

2000

1500

1000

800

700

600

500

400

300

200

100

\section{Figure 3}

CvLIP4 gene amplification in different culture media. Legend: TR: tributyrin; TO: triolein; O: olive oil; G: glucose. 